\title{
FINNIC LANGUAGE ISLANDS IN EASTERN LATVIA: ARCHAEOLOGICAL BACKGROUND AND PERSPECTIVE
}

\author{
Heiki Valk \\ University of Tartu, EE \\ heiki.valk@ut.ee
}

\begin{abstract}
This article discusses the archaeological background of the Leivu and Lutsi Finnic language islands. In contrast to the earlier research tradition, a hidden Finnic presence is suggested by the distribution area of Roman Iron Age tarand graves up to and including the Medieval Period when the presence of a Finnic population in northeastern Latvia ("the Chud in Ochela") is noted in 1179/80. The Leivu language island west of Alūksne may be the last descendants of this population, formed by the merging of a Finnic substrate and Latgalian superstrate and standing between the Estonians and Livonians. The borders of this Finnic area in northern and northeastern Latvia a diverse network of communities, existing in parallel with Latgalian ones and based on various ethnic components - are difficult to determine, as archaeological traces of its cultural pattern in the 12th-14th centuries have much in common with the Latgalians despite definite peculiarities. The Finnic traces in the Lutsi area are more difficult to identify archaeologically, although physical anthropology suggests a former Finnic presence there too.
\end{abstract}

Keywords: archaeology, Iron Age, medieval, eastern Latvia, Latgale, Atzele, Leivu, Lutsi

DOI: https://doi.org/10.12697/jeful.2021.12.2.04

\section{Introduction}

The origin of the Finnic language islands of eastern Latvia has been a topic of discussion since the beginning of research interest in them in the late 19th century. Their genesis has been explained in different ways - both from the perspective of autochthonic roots and as resulting from immigration from Estonia. In earlier research, this question has traditionally been raised from a linguistic or historical perspective. The aim of this survey is to discuss this topic from an archaeological point of view, challenging some traditional approaches, and to disseminate ideas 
emerging from an archaeological context to a neighbouring discipline historical linguistics.

\section{The broader background: The Finnic past of eastern Latvia}

\subsection{The origins of the Finnic population}

In research since the early 1930s (see: Lang 2018: 35-41) but especially since the 1950s (Moora 1956: 53-54, Jaanits 1956: 135-139), the Finnic languages were considered to have arrived in the eastern Baltic area together with Comb Ware around $3000 \mathrm{BC}$. This theory was based on assuming a direct connection between archaeological cultures (with definite elements of the archaeological record ascribed to them) and languages. In the 1990s, this theory was abandoned, since there exist no direct universal connections between languages and elements of material culture. The fictional nature of "archaeological cultures" was shown by the non-overlapping character of different elements of the archaeological record also in the eastern Baltic region (Lang 2001).

For a long time there existed a considerable difference in the answers given by archaeologists and linguists to the question of when did the Finnic languages appear in the eastern Baltic region. While archaeological interpretations, based on the theory noted above, spoke of a 5000-year presence, linguistics accepted a much shorter time period. This contradiction was recently overcome through synthesis of archaeological and linguistic data - a new approach based on looking for changes in the archaeological record during the approximate time period suggested by linguistics.

This study, published first in Estonian (Lang 2018) and later, following the addition of some new information based on ancient DNA research, also in Finnish (Lang 2020) presents the theory that the speakers of the Proto-Finnic language arrived from the Volga region in the Late Bronze Age and Early Iron Age. They were in close contact with the early Baltic-speaking population already on the way, which is the reason for the presence of early Baltic loan words in the Finnic languages. The Finnic arrival which started, based on the archaeological record, probably at the turn of the $2 \mathrm{nd}$ and 1 st millennia $\mathrm{BC}$, is regarded not as a one-time event, but as a long-term process - as a population flow 
or a number of different migration waves or a combination of both. This migration was not a straightforward movement towards the west, but a process of broad settlement expansion - a creation and development of new settlement units. The arrival of this new population is connected with a broader phenomenon characteristic of that time - the genesis of fortified settlements (or early hill forts) which were founded in the eastern Baltic region on both the later Baltic and Finnic territories, giving evidence of population growth and power consolidation. The development of fortified settlements at that time was, however, not a specific feature connected with the Finnic migrations, but a part or expression of a much broader phenomenon during that time: strongholds of that kind were built then across all of the northern part of Europe where the economy was based on agriculture.

The main route of the Proto-Finnic immigration (Lang 2018: 204225) entered eastern Latvia from Pskov Land and northern Belarus following the large Daugava waterway, passing through Latvia and reaching the Baltic Sea. Having reached the sea, these immigrants continued to the Curonian peninsula and Saaremaa, and along Estonia's western coast to northern Estonia which became, as a result of cultural consolidation and population growth, the basis for further territorial expansion and the birth of other Finnic languages.

This expansion can be observed in the archaeological record, both in the distribution of a new type of pottery and in the appearance of a new grave form - the early tarand graves - irregular clusters of rectangular cell- or chamber-like burial structures (tarands) built on the surface of the ground (Lang 2007: 170-191, 2018: 168-174). The prototypes of this type of cemetery can be found in the Volga region where the dead were buried in "houses of the dead" - also cell-like rectangular structures, but made of timber. However, in Estonian coastal areas the tarand cells were built using stone instead of timber. The idea to construct stone graves - a tradition widespread in Scandinavia - originates from the earlier Germanic population, which inhabited the coastal areas of Estonia, Finland, and Courland before the Finnic arrival and buried their dead mainly in circular stone graves.

The societal processes caused by the arrival of a new population and the related settlement expansion can be connected with changes in language. Archaeology makes it possible to suggest regions where linguistic changes and contacts may have taken place. The two populations 
and traditions mixed along the Baltic Sea coast, as shown by the presence of stone cist graves and early tarand graves in the same cemeteries during the pre-Roman Iron Age. Finnic language use ultimately dominated, but the earlier Scandinavian presence and contacts are evidenced by early Germanic loan words.

According to various linguistic studies (Sammallahti 1977, Viitso 1985, Kallio 2014), the South Estonian language is the result of the first separation from Proto-Finnic. This separation has now been connected with a specific region and time, i.e., with the people who "dropped off" from the general immigration route in the eastern part of eastern Latvia extending, maybe somewhat later, to southern Estonia. The second separation from Proto-Finnic, that of the Livonian language, can be related to the more western territories of Latvia.

\subsection{The Roman Iron Age and its decline}

Finnic culture in Latvia becomes archaeologically visible when pottery with textile impressions appears around the turn of the era (Vasks 1991). This kind of ware, common also for the Finnic areas of the Volga region, represents a tradition different from the striated pottery of the Baltic cultures.

The Finnic peculiarities clearly emerge beginning with the transition to the Roman Iron Age (dated as 0-400 AD in Latvia, 50-450 AD in Estonia) and are expressed by a new grave type, i.e., the typical tarand graves. These monumental graves built of large granite boulders follow the cell-based structure of early tarand graves, but instead of irregular clusters, the burial "chambers" are now organised in rows. The new

grave type appears in southern Estonia in the 2nd century via cultural impacts or immigration from the south - present-day Latvian territory (Laul 2001: 192). In the Roman Iron Age, the border between Finnic and Baltic cultures is clearly reflected in the archaeological record by burial traditions. While the Balts inhumed the dead in big sand barrows with collective burials (Vasks 2001: 214-229), the Finnic population practised cremation, with ashes dispersed in tarand graves.

Most finds from the tarand graves of eastern Latvia reached archaeological collections already in the 19th century, and the material was analysed in detail in the 1930s (Moora 1929; 1938). The tarand graves of Vidzeme and Latgale have not attracted later research interest in Latvian archaeology and since that time no new excavations have 
followed. Later surveys presented in general treatments of Latvian prehistory (LA 1974: 106-108, 130, Vasks 2001: 224-229) are heavily based on earlier material and conclusions.

Among the tarand graves of eastern Latvia, three main regions can be distinguished - the Gauja basin, central Vidzeme, and Latgale - each characterised by its own peculiarities (Laul 1982: 243-246, table XIV). The latter two areas also involve, respectively, the Leivu and Lutsi Finnic language islands: in both cases several stone setting cemeteries are known from the region. In general, however, the Roman Iron Age culture was very similar in southern Estonia and eastern Latvia, and on a broader scale, it can be treated as one cultural entity. Recent analysis of jewellery from tarand cemeteries shows close communication among the communities of southeastern Estonia, northern Vidzeme, and central Latgale (Olli 2019).

The Roman Iron Age culture flourished in eastern Latvia until the 5th century when the construction of new cemeteries and new tarand graves ended, and the latest finds date to the 6th century (Urtāns 1970: 76-79). The same process can also be seen in Estonia where about $80 \%$ of tarand graves were abandoned in the mid-5th century, while in northern Estonia continuity into the Migration Period can mainly be observed (Tvauri 2012: 254). Their final decline might correlate with the global climate catastrophe of 536/537, known both from written sources of the Mediterranean region as well as from sediments at the bottom of bodies of water (Tvauri 2014). The volcanic dust, which covered the sun for two years and caused the death of crops, was fatal for Northern Europe where a general decline of population and settlement can be observed in the 6th century. Roughly at the same time, there is written evidence of Justinian's Plague which killed about one-third of the population in the Mediterranean region in 541-543. There is no written evidence of the pandemic in the Baltic Sea region, but, considering oversea transmission, it may also have contributed to the decline in culture and population.

\subsection{The Dark Ages: Disappearance, assimilation, or continuity?}

In general, the abandonment of tarand graves has been regarded as a sign of the disappearance of the Finnic population in northern Latvia, as Finnic burial rites have been connected exclusively with stone graves. The fate of the Finnic population of eastern Latvia after the end of the Roman Iron Age has not attracted research interest in Latvian 
archaeology for a long time - the latest article on the topic was published more than fifty years ago (Urtāns 1970) - and the focus in ethnic studies has been on the history of Baltic tribes. The expansion of the Latgalians, whose material culture and burial rites differed from those of the Finnic population - the Balts in Latvia practised inhumation - began in the 6th and 7th centuries. By the 9th-10th centuries, the area they occupied is believed to have reached the mostly uninhabited and forested border areas between later Estonian and Latvian territories (Radinš 2006: 142-143), but also their later, 11th-12th century arrival at the EstonianLatvian border areas has been suggested (Ciglis 2009, 35).

The history of the Finnic population in eastern Latvia following the end of the Roman Iron Age has been regarded as a history of decline and assimilation that has generally been believed to have ended in the Viking Age. A foothold for following the chronology of this process is craniological data from Kivti cemetery (Šnore 1987): graves from the 8th and 9th centuries have been attributed to the Finnic population whereas burials from the 10th to 12th century have features common for the Balts with, however, also a certain continuity of Finnic traits (Denisova 1977: 137-139, 1990: 69-71). The case of Kivti was regarded for a long time as the latest archaeological evidence of an autochthonous Finnic population in eastern Latvia.

In Latvian archaeology, the eastern part of present-day eastern Latvia, east of the areas occupied by the Livonians, has been regarded as fully Latgalian on the eve of the Crusades (LA 1974: 222-226, 277, Turlajs 1998: 12, Vasks 1997: 69; Ciglis 2016, 15, fig. 1). While a mixed Baltic-Finnic population was considered possible in the borderlands of the Livonian area, this possibility has been ruled out for eastern Latvia. Traditionally, the Finnic question has arisen in the archaeology of Vidzeme only with the emergence of the Livonian culture in the second half of the 10th century in the Lower Daugava and since the 11 th century in the Gauja basin.

However, drawing parallels with the archaeological record of southern Estonia, makes it possible to propose a different history. As in Latvia, the construction of tarand cemeteries also came to an end in Estonia during the Migration Period when they were, as a general rule, abandoned. While in most of Estonia they were replaced by stone settings of irregular structure (clusters of stones with dispersed 
ashes and grave goods), in southeastern Estonia - as well as in central Vidzeme and Latgale - the tradition of stone settings came to an end.

The abandonment of stone graves, however, does not mean the disappearance of the Finnic population (Valk 2018). In spite of the lack of known cemeteries, numerous hill forts and settlement sites indicate the continuity of settlement in southeastern Estonia from the 6th to 11 th century. Evidently, in connection with the cataclysms and societal changes of the 6th century, major changes took place in funerary practices: after abandoning the tarand graves, the surviving Finnic communities began to bury their deceased in a way which has left almost no trace in the archaeological record. Most likely, the ashes without grave goods were buried in flat graves with no stone constructions. In addition to pit graves, there may have existed larger burial plots with cremains dispersed on their bottom, i.e., at a depth below strata disturbed by ploughing (Valk \& Allmäe 2010, Valk \& Laul 2014: 65).

Considering the cultural unity of the tarand cemeteries in southern Estonia and eastern Latvia, and the similar fate of the sites during the Migration Period, it seems logical to suggest that similar cultural processes continued within the whole area of this cemetery type also in the 6th-12th centuries. Most likely, as in southeastern Estonia, the Finnic population of northern Latvia also followed some archaeologically almost invisible type of burial rites after abandoning the tarand graves (Valk 2018). Thus, the lack of "Finnic graves", i.e., stone graves in eastern Latvia, cannot be interpreted as a sign of the absence of a Finnic population.

The main difference between the developments in the areas of present-day Estonia and Latvia was the share of Baltic immigration which strongly influenced population processes in eastern Latvia. The ratio of indigenous vs. immigrant inhabitants is a great question concerning the ethnic history of the region. The "invisible" character of Finnic graves of that period makes it extremely complicated to distinguish the share of different ethnicities or to follow the process of assimilation and interactions of different ethnic groups during specific time periods.

Shifts in estimating the length of the period during which the Finnic population persisted have taken place only during the last years. Thus, the presence of a mixed Latgalian-Finnic (Chud) population has been noted in the former Abrene district (presently in the Russian 
Federation) - in the 13th century lands of Abrene and Purnava (Ciglis 2016: 15) - and the idea that there was continuity in the Finnic population of the tarand graves area (Valk 2018) is mentioned in the most recent general work on Latvian archaeology where the preservation of this population in parallel with the Latgalians in northeastern Latvia in the second half of the 1st millennium and 2 nd millennium BC is briefly noted (Vasks 2021: 579).

\section{The end of the Iron Age and transition to the Medieval Period}

\subsection{Inhumations reappear}

In most of southeastern Estonia, ${ }^{1}$ burials reappear in the archaeological record only in the late 10th or 11th century - firstly, during the Late Viking Age, as flat cremation graves with no stone constructions. Graves, still very poorly known from the final centuries of prehistory, become more numerous in the region only following the transition to inhumation practices caused by the pre-Crusade influences of Orthodox Christianity, but mainly resulting from the conquest and Christianisation of 1215-1224 (Valk 2018). Burial practices become generally visible in the archaeological record, however, only beginning in the mid-13th century when numerous village cemeteries (Valk 2001a) appear.

It seems likely that similar developments took place also in the burial practices of the Finnic communities in northern and eastern Latvia. Thus, the inhumation graves of eastern Latvia known from the 13th century, and maybe also from the 12th century, cannot unambiguously be treated as examples of Latgalian inhumation practices - as has traditionally been held - because their Finnic affinity is equally possible. We can presume that, as in southeastern Estonia, the Finnic population reappears in the archaeological record of cemeteries together with a transition to the practice of inhumation.

1 The situation was different in the eastern part of Vorumaa which was involved in the distribution area of the so-called "Pskov group of long barrows" (Aun 1992). The burial sites of this population, which inhabited mainly sandy areas with pine forests from the 6th to the 9th/10th centuries and is characterised by great homogeneity of material culture (Mikhailova 2014), are of a similar character as those in Estonia, Pskov Land, and northeastern Latvia. Different researchers have different opinions in terms of their ethnic origin but agree in terms of their belonging to one population group. 


\subsection{Written sources: The 12th and 13th centuries}

The monoethnic attitudes towards the ethnic situation in eastern Latvia on the eve of the Crusades, which have prevailed in Latvian archaeology, seem to have their roots in the Chronicle of Henry of Livonia (HCL 1982, IK 1993) - a text which speaks about the native inhabitants of the regions under discussion in clear and simple terms as Lettones, Livones, and Estones. This text, most of which was probably written in Rubene, $10 \mathrm{~km}$ southwest of Valmiera where its author Henry was the priest of a local Latgalian/Latvian congregation, does not concern the northeastern and eastern regions of Latvia, which were not the target of Crusades, or the ethnic situation in those regions.

It must be noted that the province of Atzele, which was located in the northeasternmost corner of Latvia and was divided between the bishop of Riga and the Order of the Sword Brethren in 1224 (Bunge 1853, I: no. 70 ), is not mentioned in the chronicle at all. We also should consider that the focus of Henry's text was the conquest of Estonia, but that there is no reason to regard the Finnic population of eastern Latvia as Estonians.

The Latvian archaeological research tradition has fully neglected another written source - the Novgorodian First Chronicle which mentions the raids of 1111 and 1179/1180 against Ochela (Nasonov 1950: 203, 225) - an area which has traditionally been identified with Atzele, mentioned in 1224 (Auns 1999). In the context of the raid of 1179/1180, it is explicitly stated that the province was inhabited by the Chud: "in winter went [Prince] Mstislav with the Novgorodians against the Chud, against Ochela and burnt all their country, but they fled to the sea, and many of them were killed there" (Auns 1999: 225). These words unambiguously refer not to the Baltic, but to the Finnic identity of the region, which was so clearly evident that it was also perceived as such from an outsider's position. Evidently, in the late 12th century, Finnic identity prevailed in the northeasternmost corner of Latvia.

In this context we also must consider another factor, namely, the information in the Pskov and Novgorodian chronicles on the military activities against "Ochela" and "the Chud". In the warfare of that time, a military raid was followed by a similar revenge raid soon thereafter. It is significant that raids against Ochela appear in the chronicles in the context of the same block with those against the Chud or into Estonia (Mäesalu 2020: 350-351). Thus, in 1111, Prince Mstislav raided Ochela; 
in 1113, he defeated the Chud "at Bor" - probably, in the context of their counterattack (Nasonov 1950: 204). The Novgorodian raid of Otepää in 1116 (Adrianovoj-Perets 1999: 267) was likely caused by the incursion of 1113. The raid against the Chud of Ochela in 1179/1180 may have been a punishment for 1176/1177 when "the whole land of the Chud" attacked Pskov. Thus, we can suggest a military alliance and cooperation between the Estonians and the inhabitants of Ochela, defined as Chud in 1179/1180. The size of the Novgorodian army in that invasion of Ochela is given as 20,000 men (PSRL IV: 15) - a large number even if exaggerated, which provides evidence of the large size of the territory and population of Finnic Atzele. Notes about the same raid say that the Chud fled "to the sea", but were followed and slaughtered there by the Novgorodians. Here, probably, we can find a hint of the Gauja waterway which, when frozen in winter, was a perfect track for long-distance communication and could serve as a communication channel between the Livonians and the Finnic people of Atzele/Ochela also in earlier and later times.

The geographic borders of Atzele are not easy to define based on written sources. In the treaty of 1224 , in addition to Atzele, four other territorial units - Abrene, Ābelene, Bērzene, Purnava - are noted and it remains unclear if these are regarded as parts of Atzele or as adjacent areas. Latvian historian Muntis Auns (1999) considers Atzele in a narrower sense - as the direct hinterlands of Alūksne hill fort. However, the army of 1179/1180 seems too large for looting such a limited territory suggesting a larger territorial extent for Atzele. In any case, the western border of Atzele is supposed to have extended to the Teutonic Order castle in Gaujiena (Koivaliina) called Atzel in German. Regardless of whether it was meant in the broader or narrower sense, Atzele involved the lands of the Leivu language island located between the medieval power centres of Alūksne and Gaujiena.

\subsection{The archaeological record from the 12 th to 15 th centuries}

\subsubsection{The cemetery of Siksälä}

From an archaeological perspective, the question of Finnic identities in northeastern Latvia during the Medieval Period emerged in connection with the excavations of Siksälä cemetery in the southeasternmost 
corner of Estonia in 1980-1993 - a site with furnished cremation graves from the 11th to 14th/15th centuries and inhumations from the 13th to 15 th centuries (Laul \& Valk 2007, Valk \& Laul 2014, Valk, Ratas $\&$ Laul 2014). The excavation results greatly differed from those of the ordinary medieval village cemeteries of Võrumaa (Valk 2001a) revealing a find assemblage characteristic of northeastern and eastern Latvia. The cultural peculiarities were expressed, first and foremost, in the female costume characterised by headbands with long hanging tassels (Latv. vainags) and shawls (Latv. villaine).

The burial rites of Siksälä cemetery (Valk \& Laul 2014: 62-128) differ, however, from the Latgalian traditions. While the Latgalians practiced inhumations in the Late Iron Age, the dead of the Siksälä community were cremated until the early 13th century with their ashes dispersed over an area with an irregular cluster of small, mostly fistsized cremated stones. Likewise, it was common in Baltic inhumation graves for men and women to be buried with their heads in opposite directions during the Iron Age and at the transition to the Medieval Period. However, while the Latgalians headed men towards the east, and women towards the west, the gender-based opposition in Siksälä followed the opposite direction. As in the medieval village cemeteries of Võrumaa, the men of Siksälä were oriented with their heads towards the southwest, and women towards the northeast. A specific feature of burial rites at Siksälä cemetery is also the presence of barrows with internal stone constructions: in several cases the grave pit was surrounded at ground level by a frame of rocks. Such zhalnik ${ }^{2}$ type structures are alien to Latgalian cemeteries but are common for the Novgorod and Pskov Lands with a Finnic substrate population. Most likely, the mixed character of burial rites, differing from the Latgalian practices and those of southeastern Võrumaa, indicates a separate identity which had formed as a result of the merging of the local Finnic substrate population with the Latgalian superstrate. Thereby in identity and language use, judging by the record on 1179/1180, Finnic features remained prevalent.

Although the headbands and shawls decorated with bronze clips found in Siksälä cemetery are regarded as Latgalian, in the context

2 Zhalnik, a loan word from Russian, designates different stone structures at ground level around the grave pits of inhumation graves. Zhalniks were widespread in Novgorod and Pskov Land from the 11th to the 15th centuries. 
of ethnocultural interpretations we must note another feature most characteristic for the site - the broad, shield-shaped bracelets (Valk \& Laul 2014: 115-117, Valk, Ratas \& Laul 2014), the concentration of which is the highest in the area surrounding Alūksne. Judging by their design, ornamentation, and parallels in Finnic areas, flat thin bracelets have been regarded as elements of Finnic culture (Vaska 2006) and also have not been found in the Latgalian core areas in the middle course of the Daugava River where the principalities of Jersika and Koknese existed in the early 13th century (Vaska 2006: fig. 2). The distribution area of shield-shaped bracelets (Vaska 2006: fig. 2) and wide thin bracelets in general (Vaska 2017: fig. 21) in Vidzeme greatly overlaps with the distribution area of tarand graves in Latvia. There are even two finds from northern Courland - from Puze cemetery ca. $25 \mathrm{~km}$ southeast of Ventspils. These finds in general can be regarded as a sign of Finnic identity or, at least, that their distribution area greatly overlaps with the area of earlier Finnic communication networks.

Considering the cultural pattern characteristic of eastern Latvia, the multitude of features regarded as "Latgalian", and differences from the 13th-15th century cemeteries of Vorumaa, there is no reason to regard Siksälä as an Estonian burial site - the dissimilarities are so large that such an interpretation can be ruled out. Most likely, Siksälä cemetery with material culture characteristic of eastern Latvia, should be regarded as a representative of a separate identity - the Chud of Ochela, known from written sources. This identity - Finnic in language use, but greatly of "Latgalian" character in fashion and costume - was evidently formed as a result of the merging of a local Roman Iron Age Finnic substrate population with the Latgalian superstrate (Laul \& Valk 2007: 109-122, Valk \& Laul 2014: 185-187).

\subsubsection{Archaeological traces of the Chud of Ochela}

How big was the land of Ochela? Mentions of the raids against Ochela in the Novgorodian chronicles, which reflect only large-scale military events, and the size of the army of $1179 / 1180$ clearly indicate the large extent of the territory inhabited by this Finnic population.

Although there is no written evidence, the size of the area is indirectly indicated by the distribution of cemeteries with cultural features/ patterns characteristic of Siksälä cemetery (see Figure 1). In the north, 
judging by archaeological finds, the occupation area of the Chud of Ochela probably involved the southern peripheries of the eastern part of present-day Võrumaa, as shown by finds from Krabi and Loosi (Valk \& Laul 2014, 181, Valk et al. 2018). Archaeological data show that the occupation area of this ethnic group also extends to the southern and southwestern parts of Setomaa - areas which were probably politically subordinate to Izborsk hill fort in the 12th century, at least in the vicinity of the Izborsk-Alūksne road. In Setomaa, finds similar to those from Siksälä have been found in the cemeteries of Kendishi and Vinski. ${ }^{3}$

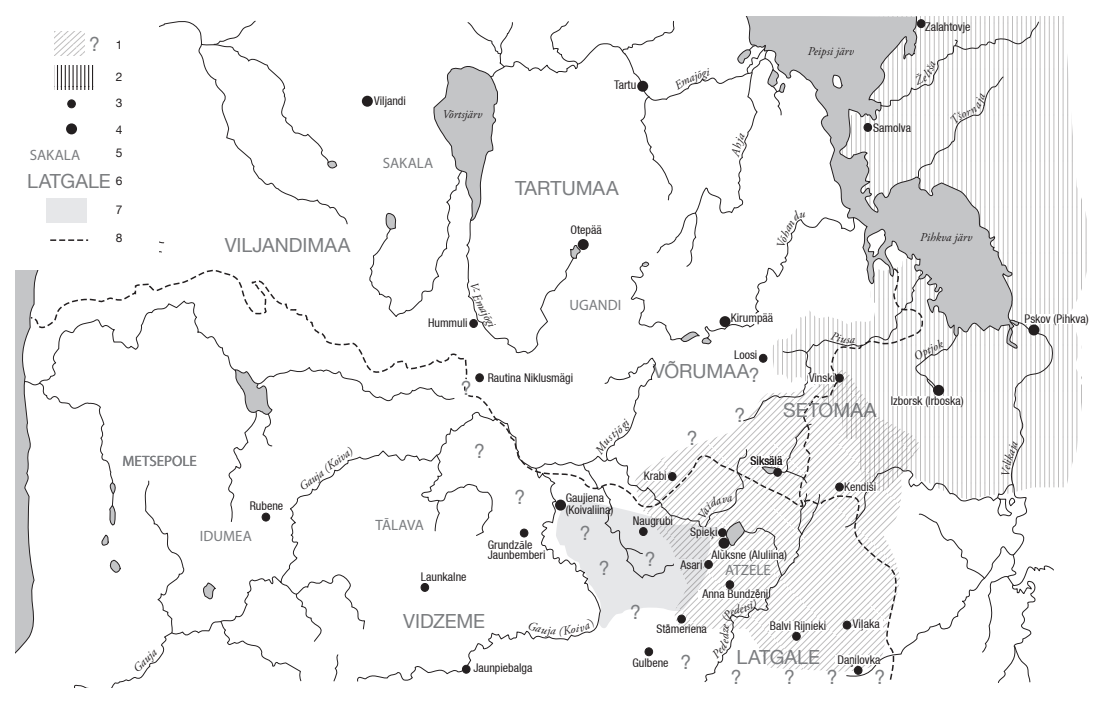

Figure 1. The occupation area of the Chud of Ochela and the Leivus. (According to Valk \& Laul 2014, fig. 123). 1 - the presumed occupation area of the Chud of Ochela (question marks designate unknown borders), 2 - the cultural area of Pskov Land, 3 - sites mentioned in the text, 4 - central places in the 12th-14th centuries, 5 - historical provinces of the 13th century, 6 - historical areas of the 19th and 20th centuries, 7 - the area inhabited by the Leivus, 8 - present-day national borders. Map design: Jaana Ratas.

However, without any doubt most of the territory of the Chud of Ochela was located in northeastern Latvia where several cemeteries show cultural similarity with Siksälä cemetery. An important indicator is the distribution of shield-shaped bracelets, the main concentration

3 In Russian archaeological literature known as Murashkino. 
area of which lies in the northeastern part of Latvia. They are also most numerous in the find assemblage of Vilaka cemetery located in the northeasternmost corner of the country (Bitner-Wróblewska et al. 2005: 73-112, Pl. XIV: 1-165, Pl. XV: 1-27) where the toponym also indicates the Finnic past of the region. The distribution of these bracelets, most numerous in Siksälä, however, definitely extends beyond the borders of Atzele and involves large areas in northern Latvia indicating a Finnic presence and communication networks.

Another specific feature of eastern areas of Finnic culture is hollow horse-shaped pendants from the 13th and 14th centuries, This find group, most numerous in Ingermanland, is present also in northeastern Latvia, indicating a communication crescent which linked the Votian land with the territories of the Livonians in the Lower Daugava region (Valk 2001b). A peculiarity characteristic of northeastern Latvia, but alien to core areas of Latgalian occupation as well as to Livonian territories, is tiny anthropomorphic pendants, most numerous in Siksälä cemetery (Valk \& Laul 2014, 112, fig. 89: 2- 7). Judging by their distribution, these finds might be regarded as signs of a Finnic presence in northeastern Latvia too.

Finnic traces in northeastern Latvia are also evidenced by the presence of cemeteries with stone constructions at ground level - both zhalnik graves and irregular low stone clusters between the zhalnik boundaries of graves. Such burial sites are atypical for Estonia but common for Pskov and Novgorod Lands - including Ingermanland and Karelia - in the 13th and 14th centuries, and have been excavated in Balvi Rijnieki (Laul, Graudonis 1965) and Danilovka (Šnore 1980, Kalējs \& Gerhards, 2018) cemeteries located ca. 40 and $70 \mathrm{~km}$ southeast of Alūksne, respectively. As this type of site is difficult to distinguish prior to excavation, their number may actually be larger within Atzele, especially in its eastern areas.

Possible traces of Finnic identity in the Latgalian territories are also suggested by other features of burial rites, e.g., deviation from Latgalian grave orientation. While graves oriented with the head towards the west cannot be regarded as ethnic markers after the spread of Christianity - at that point local traditions became mixed with and overshadowed by the common Christian practice of burying all dead facing east - the focus should instead be directed towards female graves with a non-western orientation. For example, in the 13th-14th century cemetery of 
Dzelzava, ca. $30 \mathrm{~km}$ southwest of Gulbene, 5 out 7 female graves were oriented with the head between NEE and SE (Šturms 1930). Eastoriented graves occur sporadically in different parts of eastern Latvia (Muižnieks \& Vilcāne 2002), but in the northeast this might be due to Finnic tradition (e.g., in Siksälä). As statistical data of "non-Latgalian" orientation are viewed as a whole without indicating their date or region (Muižnieks 2006, 2008, 2015: 102-105), it is difficult to describe and interpret possible local peculiarities.

The question of ethnic affinity also concerns the Late Iron Age barrow cemeteries with inhumation graves in northern Vidzeme and Latgale and dating to the 11th to 13th centuries. Although cemeteries of this type mainly found up to a distance of 50-70 km from the eastern border of Latvia have been attributed to the Latgalian population (Radiňš 1999: 35-52; fig. 22), this approach can at least partly be questioned. The reasons for the practice of burying the dead in barrows in the easternmost periphery of Latvia are not known. Evidently, the roots of this practice can be connected to the tradition of the "long barrows of the Pskov group", the ethnic backgrounds of which are, however, unclear from an archaeological perspective. Although the grave goods found in barrows with inhumations are of a Latgalian character, and the orientation of the related inhumation graves follows the Latgalian pattern, craniological features of medieval burials in the region differ from those of the Latgalians and are similar to those of the medieval cemeteries of southeastern Estonia and the formerly Finnic areas of northwestern Novgorod Land (Denisova 1977: 131-133). In terms of physical anthropology, these cemeteries form a clearly distinct cluster, separate from that of the Latgalian burial sites (Denisova 1990: 69-76, fig. 4, table 6). A non-Latgalian attribution of barrows can also be proposed for those in the basin of the Gauja River in northern Vidzeme. In this context, we must note the archaeologically investigated cemetery with 12th-13th century barrow graves in Jaunpiebalga, $40 \mathrm{~km}$ west of Gulbene. The craniological features of the population resemble those of people buried in the barrows of eastern Latvia (Denisova 1977: 131-133). When considering the fact that barrow cemeteries were characteristic for the Gauja Livonians and Siksälä cemetery, we should also consider an at least partly Finnic interpretation for such graves in the Roman Iron Age Finnic areas of eastern Latvia. 
It cannot be ruled out that the area of the Chud of Ochela may have also extended to present-day Estonia in the vicinity of Valga/ Valka where archaeological material refers to a situation different from that in the core areas of Estonia at the end of the Iron Age. For example, in Hummuli, 12th century barrows (tumuli) - a grave form alien to Estonians - both with inhumation and cremation burials and finds of an Estonian character have been studied (Hausmann 1897). Ca. $10 \mathrm{~km}$ southeast of Valga, vainags and villaine remains characteristic of eastern Latvia were found in the medieval cemetery of Rautina Niklusmägi (Valk et al. 2013). From both of these cemeteries, there are also examples of flat stone settings corresponding to Finnic traditions. Evidently, Rautina Niklusmägi cemetery did not belong to the Estonian land of Ugandi, because Lake Rautina was the site where Christian armies assembled before their raids into that province (Valk et al. 2013: 125-127). A similar cultural pattern of ethnic heterogeneity probably continued into adjacent territories in the northern border areas of Latvia. The find assemblage from Grundzāle Jaunbemberi 13th14th century cemetery ca. $10 \mathrm{~km}$ southwest of Gaujiena - also where a double-headed Finnic horse-shaped pendant was found (Cimermane 1971) - is largely similar to that of Rautina and Siksälä.

The distribution of Estonian jewellery items across Latvian territory - a topic which requires further study - could also indicate involvement in Finnic communication networks. As an example, we can note that typical Estonian jewellery from the late 12th-13th centuries has been found at the cemetery of Pāvulkalns near Launkalne, $35 \mathrm{~km}$ east of Cēsis and $45 \mathrm{~km} \mathrm{SW}$ of Valga/Valka (Siatkovskis 1986: fig. 17: 1, 2).

Thus, taken together, the extent of the territory occupied by the Ochela Chud to the southeast, south, southwest, west, and northwest of Alūksne is unclear. Although current research does not make it possible to define any definite border, it seems highly likely that it involved the territory of Atzele in a broader sense, i.e., it included Abrene, Ābelene, Bērzene, Purnava as well as the southern part of what would later become Setomaa and areas on both sides of the present-day border between Latvia and the Estonian district of Vorrumaa. These areas were not inhabited by the Latgalians, but by a non-Estonian Finnic or a Finnic-Latgalian mixed population.

Evidently, the core areas of the Chud of Ochela were subordinate to the hill fort of Alūksne, which acted as an important stronghold on 
the way from Pskov and Izborsk to two key directions. First, to the lands of the Latgalians of Tālava who were taxed by Pskov in the early 13th century and had accepted Orthodox Christianity before the arrival of the Germans and, second, to the south along the Aiviekste River to Koknese, an important centre on the Daugava waterway.

\section{The archaeological record of the Leivu and Lutsi language islands}

Archaeological monuments within the area occupied by the Leivus the lands between Alūksne, Gaujiena, and Gulbene, which in the Late Iron Age were part of the land of Ochela/Atzele - have been poorly studied (Donina \& Gusicka 2014). They certainly belonged to the direct hinterlands of the hill fort on Alūksne Tempḷa kalns, first excavated in 2016. The investigation results show that the stronghold which was founded in the second half of the 1st millennium remained in use after the establishment of Medieval Livonia (Kalējs \& Vilcāne 2018), probably until the construction of the stone castle of Marienburg on the island in Lake Alūksne in 1342. The finds from the site include a hollow Finnic horse-shaped pendant (ibid.: fig. 2: 1)

Archaeological data from cemeteries in the Leivu area (Doniņa \& Guščika 2014, Kazaine 2015: 73) are not numerous and the only excavated site within the territory is in Naugrubi near Trapene. However, small-scale excavations have taken place in the immediate vicinity of the historical Leivu area. Trial excavations on Spieki cemetery $3 \mathrm{~km}$ north of Alūksne stronghold (Atgāzis 1980, Donina 2015) revealed, as in Siksälä, in addition to inhumations a 13th-14th century cremation grave. In Asari (4.5 km southwest of Alūksne, on the north shore of Lake Indzeris), two burial sites are located in the immediate vicinity to each other. In the cemetery of Asari I, the archaeological record from the 9th to 12th centuries (Atgāzis 1984) is of a Latgalian character and in Asari II cemetery (Kalejs 2016), a male grave with an eastern orientation containing a sword was found, but a 13th-14th century hollow horse-shaped pendant from Asari I (ANM 5448) corresponds to Finnic culture. In Annas Bundzēni cemetery $5 \mathrm{~km}$ south of Alūksne, both men and women were found among east-oriented burials, which indicates 
the parallel existence of Finnic and Latgalian traditions ${ }^{4}$. In all the cases noted above, the 13th-14th century find assemblage is similar to that of Siksälä. Stāmeriena cemetery (Žeiere 2021), ca. $10 \mathrm{~km} \mathrm{NE}$ of Gulbene with finds characteristic of cemeteries in the direct hinterlands of Alūksne, is located ca. $10 \mathrm{~km}$ south of the southernmost Leivu villages.

Although in the Latvian research tradition these cemeteries have been attributed to the Latgalians, these conclusions are based on the traditional view of the ethnic situation in eastern Latvia and on the axiomatic presumption that all inhumation graves in eastern Latvia represent the Latgalian population. However, considering the fact that accepting Christianity - evidently, not later than in 1224 in Atzele - also meant accepting Christian burial rites, there is no reason to regard 13th and 14th century inhumations as a definite indication of Latgalian culture. We equally must consider the possibility that Finnic graves, archaeologically unknown due to the character of the burial rites as well as the research state of the area, became visible only after the transition to inhumation.

In the context of the ethnic affinity of the Leivu areas, we must also recall that the 1638 Swedish land inventory mentions Finnic village names within the Leivu area. ${ }^{5}$ Evidently, the villages mentioned in 1638 existed before the Livonian War (1558-1582). The time gap between the mid-15th century - the time period until which, judging by archaeological data, the Chud of Atzele had a Finnic identity - and the first half of the 16th century is short in a long-term perspective. Thus, there seems to be enough reason to suggest continuity between the Chud of Ochela and the Leivu language island, and regard the Leivus as the last remnants of this Finnic identity and population, which was most numerous at the end of the Iron Age.

While there is enough reason to suggest this continuity between the Chud of Ochela and the Leivu population, the situation concerning the Lutsis is rather unclear. There are no indications of a Finnic presence in the find assemblage (costume or jewellery) in that region since the end of the Roman Iron Age. The main archaeological features from the region suggesting a former Finnic presence are barrow cemeteries from the 1 st millennium, craniometric data from 12 th-13th century barrows

4 Letter from Vitolds Muižnieks (National History Museum of Latvia) in September 2017.

5 Information based on Dunsdorfs 1941. 
with inhumations (Cibla, Rikopole, Isnauda) (Denisova 1990, fig. 4), and also some sporadic data of east-oriented female graves (Muižnieks \& Vilcāne 2002: 555-566). The limited number of archaeological indicators suggests the Lutsis (or at least most of the population) are not descendants of the Roman Iron Age local Finnic population, but descend from medieval or post-medieval immigrants from southern Estonia. There does not seem to be sufficient reason to suggest the continuous persistence of a Finnic identity, although, hypothetically, some genetic continuity cannot be excluded.

\section{Discussion}

Concerning the ethnic situation in eastern Latvia in the territories inhabited by the Finnic population in the Roman Iron Age, it seems to have been greatly more complicated and diverse than depicted in the chronicle of Henry of Livonia which notes the presence of three ethnicities: the Estonians, Latgalians, and Livonians. In addition to these identities, probably other, also local, identity groups existed.

The presence of such groups in western Vidzeme is noted by Henry who mentions the Idumeans and Vends (near Cēsis), It must be noted that these communities were located in the immediate neighbourhood of his Rubene parish - at a distance of no more than 15-20 km from its centre and these local identity groups, which were located on the way to Riga and in Cēsis, could in no way remain unnoticed. Considering the fact that Henry is completely silent about the Finnic population of northern Courland (Vasks 2021), except for noting the origins of the Vends of Cēsis from that region, we should not be surprised that his chronicle gives no information about the ethnic situation in northeastern Latvia. Therefore, the lack of information in the Chronicle of Henry about the inhabitants of Atzele can in no way be regarded as an argument for the population of that region having been Latgalian.

Thus, the perspective of an Estonian-Latgalian opposition as the only option does not seem relevant for the northern, northeastern, eastern, but maybe also for the central regions of Vidzeme in the Late Iron Age and the Medieval Period. Evidently, a new approach from a more flexible perspective is needed for these regions, which were Finnic in the Roman Iron Age. In other words, there is no reason to 
regard this society from the perspective of the classic trichotomy of Estonians, Livonians, and Latgalians, as instead there may have existed communities with ethnic identities, which were of a different, more diverse, vague, or local character, depending on the stage of interaction and integration of Finnic and Baltic cultures, resulting from their long history of contact. We must consider that this contact may have resulted in different outputs in different localities and communities. From the perspective of this approach, the geographic structure of such a society could be compared with that of a honeycomb, where cells of different shape and size represent populations and communities with different proportions of Baltic and Finnic components, in which the local identity units were not static, but could change over the course of time. Thus, the ethnonym the Chud of Ochela may also not have designated a clearly defined ethnic or cultural identity, but a loose conglomeration or assemblage of local groups or communities with definite peculiarities in culture and traditions, still having a common denominator - attachment to Finnic culture and language use.

A question with no definite answer is, also considering the Leivu ethnonym, the connections between the Livonians and the ancestors of the Leivus. As noted in the Chronicle of Henry in the case of the Vends, migrations of communities - both Latgalian and Finnic ones - may have taken place in the Late Iron Age and the Medieval Period also in eastern and northern Vidzeme. Signs of that have been observed in the spread of northeast-oriented graves east of the Livonian territories in the 14th and 15th centuries which has been interpreted as a mark of Livonian expansion towards the northeast (Mugurēvičs 1983). ${ }^{6}$ The analysis of craniological data from Siksälä cemetery also points to the arrival of a new population from the southwestern Livonian territories (Heapost 2007). Connections between the Chud of Ochela and the Livonians are, in addition to the ethnonym, also reflected in the language. Linguistic analysis does not regard the Leivu language, in spite of its vicinity to the Hargla dialect, as a proper part of the South Estonian language (Pajusalu et al. 2009, Viitso 2009; see also Kallio 2021 and Norvik et al. 2021 in this volume).

6 The emergence of this Finnic feature can, however, also be explained by the former "hidden" presence of the Finnic population or by the limited amount of archaeological information. 
In any case, the character of the archaeological record from northeastern Latvia shows that there is no reason to regard the Chud of Ochela as a group of Estonians, as was formerly the case (Tarvel 1975). Also, the principal error of using the term "Chud" as a synonym for "Estonians" must be corrected. We need to consider the possibility that the Finnic population of northeastern Latvia may originate from a somewhat different source than the speakers of the Vorru dialect and are the descendants of some other wave or group of early Proto-Finnic immigrants. The possibility of a deep temporal dimension for the difference with the population of Vorrumaa is supported by the observation that the Leivu language is a result of the earliest branching from southern Proto-Finnic (cf. Kallio 2021).

The genesis and earlier history of the Finnic language islands is not documented in written sources but the general nature of the processes - characterised by retreat and decline - has been recorded since the research began on these communities. Considering this, there is no reason to suggest that decline started only with the start of historical documentation and to presume an earlier static persistence of a status $q u o$ of that time. More likely, these processes were dynamic also further in the past. In other words, if there existed written records from the 10th, 14 th, or 15 th centuries, the picture would be considerably different from traditional concepts and understandings.

The situation probably changed gradually in parallel with the expansion of Latgalian communities and culture and the assimilation of the Finnic population. Due to the lack of sources, it is not possible to describe the process of assimilation during the Iron Age and Medieval Period. We can only presume that these processes accelerated once the Baltic-speaking population and settlement units became the majority in a region. Data on the reasons for assimilation can be found only at its final stage - in the 20th century. For example, by the 1940s Lutsi adults no longer used Lutsi with their children, instead communicating with them exclusively in Latvian. They did this with the aim of giving their descendants a better future in Latvian-speaking society and to save them from disparagement for their use of a different language. ${ }^{7}$ Thus, Finnic language use probably also ended in earlier times along with generational changes and shifts in language use in particular regions.

7 Memories of Jānis Buls (born in 1941) from Greči village in the Lutsi area (2008). 


\section{Conclusions}

The question of Finnic identities in northern and eastern Latvia after the decline of the Roman Iron Age tarand graves - especially from the perspective of possible connections with the Leivu and Lutsi Finnic language islands - has never been a research topic of special interest in Latvian archaeology where the focus has been on the study and expansion of Baltic identities in ethnic terms. However, written data note Atzele district as populated by the Chud in 1179/80 and the archaeological record of northeastern Latvia has certain peculiarities when compared to the core areas of Latgalian culture, while craniological features of barrows from eastern Latvia indicate similarities with Finnic populations.

Archaeological material provides no definite answer to the question of the ethnic affinity of the population of northern Vidzeme and northern and central Latgale in the final stage of the Iron Age and the Medieval Period due to the limited number of excavations and lack of targeted research from the perspective of ethnic history. Nevertheless, instead of the model of a monoethnic Latgalian population which emerges from written sources and earlier research tradition, the archaeological record is extensive enough to suggest another approach $-\mathrm{a}$ honeycomb model in which local identities of different sizes and character, with different shares of Finnic and Latgalian components coexisted. An approach based on this new paradigm could likely be a more fertile basis for further discussions of the ethnic history of northern Vidzeme and northern/eastern Latvia.

Since current research does not provide direct archaeological evidence regarding the ethnic situation in the Leivu areas in the Late Iron Age, Medieval Period, or Early Modern Period, conclusions must greatly consider information from adjacent neighbouring territories. These materials in no way allow one to regard these territories as purely Latgalian. A more likely scenario is the existence of an ethnic identity (or assemblage of local, closely related identities) based on a Finnic substrate and Latgalian superstrate, but with a predominantly Finnic character - that of the Chud of Ochela. Concerning the Lutsi area, archaeological evidence provides no definite support for the continuity of a population from the Roman Iron Age up to the 20th century. 
Although archaeology can identify features of different origins in material evidence, it cannot firmly distinguish the speakers of Baltic and Finnic languages among the population of formerly Finnic areas of eastern Latvia. Despite that, there is enough reason to look upon the questions of ethnic relations in eastern Latvia from a new perspective - that of the long-term presence of a Finnic component in parallel to the Latgalian one. The last decades have witnessed a reevaluation of the Livonian component in the making and development of the Latvian nation. A similar reevaluation and growth of interest would be welcome also in studies concerning the Finnic past of eastern Latvia.

Identification of the ratio of Baltic and Finnic components in the northern and eastern parts of eastern Latvia is a task for future ethnocultural studies of the region. Hopefully, clarity in terms of ethnic questions will be provided by new excavations and fresh interpretations as well as by results of ancient DNA analysis and comparison with those from the core Latgalian areas, from Siksälä cemetery, and other sites in southeastern Estonia.

\section{References}

Adrianovoj-Perets, V. P. (ed.). 1999. Povest'vremennyh let. Podgotovka teksta, perevod, stat'i i kommentarii D. S. Likhatšova. 2nd ed. Sankt-Peterburg: Nauka.

Atgāzis, Māris. 1980. Izrakumi Aluksnes pilī un Spieķu senkapos. In Zinātniskās atskaites sesijas materiāli par arheologu un etnogrāfu 1979 gada pētījumu rezultātiem, 17-22. Rīga: Zinātne.

Atgāzis, Māris. 1984. Pētījumi Alsviḳu ciema Asaru senkapos un arheoloǵisko pieminekḷu apzin̄āšana Alūksnes apkārtnē. In Zinātniskās atskaites sesijas materiāli par arheologu un etnogrāfu 1982. un 1983. gada pētījumu rezultātiem, 21-26. Rīga: Zinātne.

Aun, Mare. 1992. Arheologitšeskie pamjatniki vtoroj poloviny 1-go tysjatšeletija n. e. v Jugo-Vostotšnoj Estonii. Tallinn: Olion.

Auns, Muntis. 1999. Adzeles zeme. Latvijas vēstures institūta žurnāls 3. 27-43.

Bitner-Wróblewska, Anna, Jānis Ciglis \& Arnis Radiņš. 2005. Latvijas arheologiskās senlietas Polijas krātuvēs (Latvijas Kultūrvēsturiskais Mantojums Ārzemju Krātuvēs 2. Arheolog̣ija). Rīga: Latvijas Nacionālais Vēstures Muzejs.

Breidaks, Antons. 1997. Ethno-linguistic contacts between Letigallians and Selonians and Baltic Finns. In Aivars Caune (ed.), Latvian Ethnic History 3(16), 104-105. Rīga: University of Latvia.

Bunge, Friedrich Georg von (ed.). 1853. Liv-, Ehst- und Curländisches Urkundenbuch nebst Regesten. Bd. I. Dorpat: Heinr. Laakmann. 
Ciglis, Jānis. 2009. Baltijas somu un baltu attiecības Austrumlatvijā 1. gadu tūkstotī. Pa somugru pēdām Baltijas jūras krastā. Starptautiskās zināītniskās konferences materiāli, 2009. gada 23. aprīlis, Turaida, 31-36. Rīga: Zinātne.

Ciglis, Jānis. 2016. Territory and borders. Ciglis, Jānis. 2016. Territory and borders. In Vitolds Muižnieks (ed.), Ceḷa uz latviešu tautu. On the road to becoming Latvian, 13-29. Rīga: Latvijas Nacionālais Vēstures Muzejs.

Cimermane, Ieva. 1972. Izrakumi Jaunbemberu kapulaukā. In Zinātniskās atskaites sesijas materiāli par arheologu un etnogrāfu 1971. gada pētījumu rezultātiem, 58-60. Rīga: Zinātne.

Denisova, Raisa. 1975. Etnogenez latyšej (po dannym kraniologii), 131-133. Riga: Zinātne.

Denisova, Raisa. 1990. Geografija antropologitšeskih tipov baltskih plemen i etnogenetitšeskie protsessy v I - natšale II tysjatšeletija n. e. na territorii Litvy i Latvii. In Balty, slavjane, pribaltijskie finny. Etnogenetitšeskie protsessy, 28-81. Riga: Zinātne.

Doniņa, Inga. 2016. Izrakumi Spieķu senkapos un Laivu kalniņā 2014. gadā. Arheologu pétijumi Latvijā 2014-2015, 91-95. Rīga: Nordik.

Doniņa, Inga \& Elīna Guščika. 2014. Arheologiskie pieminekḷi Alūksnes un Apes novados. Rīga: LU Latvijas Vēstures Institūts.

Dunsdorfs, Edgars. 1941. Vidzemes 1638. gada arklu revīzija. 3. burtn. Rīga: Latvijas vēstures institūta apgādiens.

Hausmann, Richard. 1897. Die Gräber von Hummelshof, Allatskiwwi und Pajus. In Sitzungsberichte der gelehrten Estnischen Gesellschaft 1896, 38-39. Dorpat.

HCL 1982 = Heinrici Chronicon Livoniae. Henriku Liivimaa kroonika. 1982. Tõlkinud Richard Kleis, toimetanud ja kommenteerinud Enn Tarvel. Tallinn: Eesti Raamat.

Heapost, Leiu. 2007. The Cemetery of Siksälä: Osteological and Paleodemographical Analysis. In Silvia Laul \& Heiki Valk. Siksälä: A Community at the Frontiers. (CCC Papers, 10), 213-236. Tallinn-Tartu: University of Tartu, Institute of History and Archaeology; Gotland University College, Centre for Baltic Studies.

IK 1993 = Indriķa hronika. 1993. No latīnu valodas tulkojis Ā. Feldhūns; Ē. Mugurēviča priekšvārds un komentāri. Rīga: Zinātne.

Jaanits, Lembit. 1956. Eesti NSV territooriumi kiviaja elanike päritolust. In Harri Moora (ed.), Eesti rahva etnilisest ajaloost. Artiklite kogumik, 120-146. Tallinn: Eesti Riiklik Kirjastus.

Kalējs, Uldis. 2016. Arheologíiskā izpēte Asaru senkapu aizsardzības zonā 2014. gadā. In Arheologu pētijumi Latvijā 2014-2015, 45-49. Rīga: Nordik.

Kalējs, Uldis \& Antonija Vilcāne. 2018. Pirmie arheoloǵiskie izrakumi Alūksnes Tempḷa kalnā 2017. gadā. In Arheologu pētijumi Latvijā 2016-2017, 50-55. Rīga: NT Klasika.

Kalējs, Uldis \& Guntis Gerhards. 2018. Daņilovkas un Rikopoles senkapu postījumu sakopšanas darbi. In Arheologu pētijumi Latvijā 2016-2017, 45-49. Rīga: NT Klasika. 
Kallio, Petri. 2014. The diversification of Proto-Finnic. In Joonas Ahola, Frog Clive Tolley (eds.), Fibula, fabula, fact: The Viking Age in Finland, 155-170. Helsinki: Suomalaisen Kirjallisuuden Seura.

Kallio, Petri. 2021. The Position of Leivu. Eesti ja soome-ugri keeleteaduse ajakiri. Journal of Estonian and Finno-Ugric Linguistics 12(2). 123-143. https://doi. org/10.12697/jeful.2021.12.2.05.

Kazaine, Laura. 2015. Latvijas igauñi: Ludzas iganni un Lejasciema leivi. Latvijas Kultūras akadēmija, kultūras teorijas un vēstures katedra, Rīga. Bakalaura darbs.

LA 1974 = Latvijas PSR arheologija (1974). Rīga: Zinātne.

Lang, Valter. 2001. Interpreting archaeological cultures. Trames. Journal of the Humanities and Social Sciences, 5(1). 48-58.

Lang, Valter. 2007. The Bronze and Early Iron Ages in Estonia. (Estonian Archaeology 3). Tartu: Tartu University Press. https://doi.org/10.26530/OAPEN_423939.

Lang, Valter. 2018. Läänemeresoome tulemised. (Muinasaja Teadus 28). Tartu: Tartu Ülikooli Kirjastus.

Lang, Valter. 2020. Homo Fennicus. Itämerensuomalaisten etnohistoria. Helsinki: Suomalaisen Kirjallisuuden Seura.

Laul, Silvia. 2001. Rauaaja kultuuri kujunemine Eesti kaguosas. (Muinasaja Teadus 9 / Õpetatud Eesti Seltsi Kirjad 7). Tallinn: [Ajaloo Instituut].

Laul, Silvia \& Graudonis, Jānis. 1965. Arheologitšeskie raskopki v "Karakapi” u hut. Rijnieki Balvskogo rajona v 1946 godu. In Zinātniskās atskaites sesijas referātu tēzes par arheologu, etnogrāfu un folkloristu 1964. gada ekspedīcijām, 23-24. Rīga: Zinātne.

Laul, Silvia \& Heiki Valk. 2007. Siksälä: A Community at the Frontiers. Iron Age and Medieval. (CCC Papers 10). Tallinn - Tartu: University of Tartu, Institute of History and Archaeology; Gotland University College, Centre for Baltic Studies.

Mäesalu, Ain. 2020. Kirjalikud allikad. In Valter Lang (ed.), Eesti ajalugu I. Eesti esiaeg, 347-350. Tartu: Tartu Ülikooli ajaloo ja arheoloogia instituut.

Mikhailova, Elena. 2014. Veščevoj kompleks kul'tury pskovskih dlinnyh kurganov: tipologija i hronologija. Saarbrücken: Lambert Academic Publishing.

Moora, Harri. 1929. Die Eisenzeit in Lettland bis etwa 500 n. Chr. Teil I. Die Funde. (Verhandlungen der Gelehrten Estnischen Gesellschaft XXV). Tartu.

Moora, Harri. 1938. Die Eisenzeit in Lettland bis etwa 500 n. Chr. Teil II. (Verhandlungen der Gelehrten Estnischen Gesellschaft XXIX). Analyse. Tartu.

Moora, Harri. 1956. Eesti rahva ja naaberrahvaste kujunemisest arheoloogia andmeil. In Harri Moora (ed.), Eesti rahva etnilisest ajaloost. Artiklite kogumik, 41-119. Tallinn: Eesti Riiklik Kirjastus.

Mugurēvičs, Ēvalds. 1983. Probleme der Herausbildung der lettischen Völkerschaft im Mittelalter nach archäologischen Befunden. Journal of Baltic Studies 14(2). 99-108. https://doi.org/10.1080/01629778300000141.

Mugurēvičs, Ēvalds. 1999. Novadu veidošanās un to robežas Latvijas teritorijā, 12. gs. 16. gs. vidus. In Andris Caune (ed.), Latvijas zemju robežas 1000 gados, 75-76. Rīga; Latvijas vēstures institūts. 
Muižnieks, Vitolds. 2006. Graborientierung in Begräbnissätten aus dem 14. bis zum 18. Jh. in Ostlettland. In Heiki Valk (ed.), Etnos ja kultuur. Uurimusi Silvia Laulu auks. (Muinasaja Teadus 18), 209-225. Tallinn-Tartu: Tartu Ülikool, arheoloogia õppetool ja kabinet, TLÜ Ajaloo Instituut.

Muižnieks, Vitolds. 2008. Kapu orientācija Latvijas teritorijas 14.-18. gs. apbedīšanas vietās. Latvijas vēstures institūta žurnāls 3, 48-52. Rīga.

Muižnieks, Vitolds. 2015. Bēru tradīcijas Latvijā pēc arheologiski pētīto 14.-18. gadsimta apbedī̌sanas vietu materiāla. (Latvijas Nacionālā vēstures muzeja raksti 21). Rīga: Latvijas Nacionālais Vēstures Muzejs.

Muižnieks, Vitolds \& Antonija Vilcāne. 2002. Civitas et Castrum ad Mare Balticum. In Andris Caune (ed.), Baltijas arheologijas un vēstures problēmas dzelzs laikmetā un viduslaikos, 555-566. Rīga: Latvijas Vēstures Institūts.

Norvik, Miina, Uldis Balodis, Valts Ernštreits, Gunta Kḷava, Helle Metslang, Karl Pajusalu \& Eva Saar. 2021. The South Estonian language islands in the context of the Central Baltic area. Eesti ja soome-ugri keeleteaduse ajakiri. Journal of Estonian and Finno-Ugric Linguistics 12(2). 33-72. https://doi.org/10.12697/ jeful.2021.12.2.02.

Nasonov, A, N. (ed.). 1950. Novgorodskaja pervaja letopis'staršego i mladšego izvodov. Moskva, Leningrad: AN SSSR.

Olli, Maarja. 2019. Regions and communication in south-east Estonia and north Latvia in the 3rd and 4th centuries based on local ornaments. Eesti Arheoloogiaajakiri. Estonian Journal of Archaeology 23(2). 75-102. https://doi.org/10.3176/ $\operatorname{arch} .2019 .2 .01$.

Pajusalu, Karl, Arvo Krikmann \& Eberhard Winkler. 2009. Lexical relations between Salaca Livonian and Estonian dialects. Linguistica Uralica 45(4). 283-298. https:// doi.org/10.3176/lu.2009.4.04.

PSRL = Arheografitšeskaja komissija. 1848. Polnoe sobranie russkih letopisej, izdannoe po vysotšajšemu poveleniju Arheografitšeskoj komissiej, IV. Sankt-Peterburg.

Radiņš, Arnis. 1999. 10.-13. gadsimta senkapi latgaḷu apdzīvotajā teritorijā un Austrumlatvijas etniskās, sociālās un politiskās vēstures jautājumi. (Latvijas vēstures muzeja raksti 5). Rīga: Latvijas Nacionālais Vēstures Muzejs.

Radiņš, Arnis. 2006. The area populated by the Latgallians and the shifting of its northern boundary in the 7th-13th century. In Heiki Valk (ed.), Etnos ja kultuur. Uurimusi Silvia Laulu auks. (Muinasaja Teadus 18), 138-139. Tartu-Tallinn: Tartu Ülikool, arheoloogia õppetool ja kabinet, TLÜ Ajaloo Instituut.

Radiņš, Arnis. 2021. Jaunpiebalgas kapsētas senkapi. In Latvijas arheologiijas rokasgrāmata, 303-304. Rīga: Zinātne.

Sammallahti, Pekka. 1977. Suomalaisten esihistorian kysymyksiä. Virittäjä 81(2). 119-136.

Siatkovskis, Jānis. 1986. Izrakumi Pāvulkalna viduslaiku kapsētā. In Zinātniskās atskaites sesijas materiāli par arheologu un etnogrāfu 1984. un 1985. gada pètījumu rezultātiem, 99-102. Rīga.

Šnore, Elvīra. 1980. Pogrebenija žal'nitšnogo tipa na severo-vostoke Latvii. Latvijas PSR Zinātñu akadèmijas vēstis 12. 38-54. Rīga.

Šnore, Elvīra. 1987. Kivtu kapulauks. Rīga: Zinātne. 
Tarvel, Enn. 1975. Kas Otšela tšuudid olid Koivalinna eestlased? Keel ja Kirjandus 18(9). 549-553.

Turlajs, Jānis (ed.). 1998. Latvijas vēstures atlants. Rīga: Jāņa Sēta.

Tvauri, Andres. 2012. The Migration Period, Pre-Viking Age, and Viking Age in Estonia. Estonian Archaeology 4, 328-329. Tartu: University of Tartu Press. https://doi.org/10.26530/OAPEN_423944.

Tvauri, Andres. 2014. The Impact of the climate catastrophe of 536-537 AD in Estonia and neighbouring areas. Eesti Arheoloogiaajakiri. Estonian Journal of Archaeology 18(1). 30-56. https://doi.org/10.3176/ARCH.2014.1.02.

Urtāns, Vladislavs. 1970. Etniskās atšķirības apbedīšanas tradīcijās un kapu inventārā Latvijā 5.-9. gs.. Arheologija un etnogräfija 9. 76-79. Rīga: Zinatne.

Valk, Heiki. 2001a. Rural Cemeteries of Southern Estonia 1225-1800 AD. 2nd edition. (CCC Papers, 3.) Visby - Tartu: Tartu University Press.

Valk, Heiki. 2001b. About the Early Medieval and Prehistoric Contacts of the Votians and the Daugava Livonians. Congressus Nonus Internationalis Fenno-Ugristarum. 7.-13.8. 2000 Tartu. Pars VIII. Dissertationes sectionum: Litteratura, Archaeologia \& Anthropologia \& Genetica \& Acta Congressus. Redigit: Tõnu Seilenthal; curaverunt: Anu Nurk, Triinu Palo. Tartu. 365-374.

Valk, Heiki. 2018. Disappearance and traces of the Finnic population in north-eastern Latvia - a view from southern Estonia. In Vitolds Muižnieks (ed.), Cel̦ā uz latviešu tautu. Rakstu krājums. (Latvijas Nacionālā Vēstures Muzeja Raksti 24), 96-114. Rīga: Latvijas Nacionālais Vēstures Muzejs.

Valk, Heiki \& Silvia Laul. 2014. Siksälä kalme, I. Muistis ja ajalugu. Tartu: Tartu Ülikool, ajaloo ja arheoloogia instituut, arheoloogia osakond.

Valk, Heiki, Pikne Kama, Riina Rammo, Martin Malve \& Mauri Kiudsoo. 2013. The Iron Age and 13th-18th century cemetery and chapel site of Niklusmägi: grave looting and archaeology. Archaeological Fieldwork in Estonia 2012, 109-132. Tallinn.

Valk, Heiki, Mauri Kiudsoo \& Martin Malve. 2018. The village cemetery and chapel site of Loosi - a spot at Late Iron Age and medieval road from south-eastern Estonia to Izborsk and Pskov. In Valter Lang \& Erki Russow (eds.), Pühakud, piiskopid, linnad ja linnused. Ajarännakud kesk-ja varaunasega. Uurimusi Jaan Tamme auks. (Muinasaja Teadus 27), 145-182. Tallinn-Tartu: Tartu Ülikool, ajaloo ja arheoloogia instituut.

Valk, Heik, Silvia Laul \& Jaana Ratas. 2014. Siksälä kalme, II. Matuste ja leidude kataloog. Tartu: Tartu Ülikool, ajaloo ja arheoloogia instituut, arheoloogia osakond.

Vaska, Baiba. 2006. Ornamentation on Shield-shaped Bracelets. In Heiki Valk (ed.), Etnos ja kultuur. Uurimusi Silvia Laulu auks. (Muinasaja Teadus 18), 301-318. Tartu-Tallinn: Tartu Ülikool, arheoloogia õppetool ja kabinet, TLÜ Ajaloo Instituut.

Vaska, Baiba. 2017. Rotas un ornaments Latvijā no 13. gs. lìdz 18. gs. vidum. (Latvijas Nacionālā vēstures muzeja raksti 22). Rīga: Latvijas Nacionālais Vēstures Muzejs. Vasks, Andris. 1991. Keramika epohi pozdnej bronzy i rannego železa Latvii. Rīga: Zinātne. 
Vasks, Andris. 1997. The cultural and ethnic situation in Latvia during the Early and Middle Iron Age (1st-8th century). In Aivars Caune (ed.), Latvian Ethnic History 3 (16). Rīga: University of Latvia.

Vasks, Andris. 2001. Agrais dzelzs laikmets. 1.-400.g. In Latvijas senākā vēsture 9. g. t. pr. Kr. - 1200 g., 186-231. Rīga: Latvijas vēstures institūta apgāds.

Vasks, Andris. 2021. Baltijas jūras somi. In Latvijas arheologijas rokasgrāmata, 578579. Rīga: Zinātne.

Viitso, Tiit-Rein. 1985. Läänemeresoome murdeliigenduse põhijooned. Keel ja Kirjandus 28(7). 399-404.

Viitso, Tiit-Rein. 2009. Livonian and Leivu: shared innovations and problems. Linguistica Uralica 45(4). 269-282. https://doi.org/10.3176/lu.2009.4.03.

Vilcāne, Antonija. 2021. Daṇilovkas senkapi. In Latvijas arheologijas rokasgrāmata, 293-294. Rīga: Zinātne.

Žeiere, Irita. 2021. Stāmerienas senkapi. In Latvijas arheologijas rokasgrāmata, 357358. Rīga, Zinātne.

\section{Kokkuvõte. Heiki Valk: Lõunaeesti keelesaared Ida-Lätis: arheoloogiline taust ja perspektiiv. Artikkel käsitleb leivu ja lutsi keelesaarte arheoloogi- list kujunemist. Erinevalt varasemast, baltikesksest vaatenurgast eeldatakse läänemeresoome rahvastiku varjatud püsimist rooma rauaaja tarandkalmete alal kuni keskajani ja ka keskaja vältel - kirjalikud allikad mainivad aastatel 1179- 1180 “Otšela tšuude" (tinglikult "adsele maarahvast”). Leivu keelesaar võiks endast kujutada selle läänemere substraadi ja latgali superstraadi ühtesulamise tulemusena kujunenud ning eestlaste ja liivlaste vahel paiknenud rahvastiku viimaseid järeltulijaid. Läänemeresoome asuala piire Läti põhja- ja kirdeosas on raske määratleda, kuna ilmselt oli tegemist eriilmeliste, läti asustuse kõrval eksisteerinud kogukondade võrgustikuga ja 12.-14. sajandi rahvastiku kultuuri arheoloogilised jäljed on vaatamata teatud iseärasustele paljuski latgalipärase ilmega. Lutsi asualal on läänemeresoome jälgi arheoloogias raskem leida, kuigi füüsilise antropoloogia andmed sellele viitavad.}

Märksõnad: arheoloogia, rauaaeg, keskaeg, Ida-Läti, Latgale, Atzele, Leivu, Lutsi 